\title{
Response of Rice Varieties to Water Stress in Sokoto, Sudan Savannah, Nigeria
}

\author{
M. B. Sokoto*, A. Muhammad \\ Department of Crop Science, Faculty of Agriculture, Usmanu Danfodiyo University, Sokoto, Nigeria \\ Email: ${ }^{*}$ mbsokoto2003@yahoo.com
}

Received December 2013

\begin{abstract}
Pot experiment was conducted at the Botanical Garden of the Department of Biological Science, Usmanu Danfodiyo University, Sokoto Nigeria, during the 2013 dry season. The main objective of this research was to determine the effect of water stress and variety on productivity of rice (Oryza sativa) at Sokoto. The treatment consisted of water stress at three growth stages (Tillering, flowering, Grain filling) and unstress (control) and three rice varieties (FARO 44, NERICA 2 and FARO 15) laid out in a Completely Randomised Design (CRD) replicated three times. The result indicated that water stress significantly $(P<0.05)$ resulted to decreased in plant height, number of leaves per plant, total biomass, harvest index and grain yield. The results indicated significant $(P<0.05)$ differences among genotypes. Faro 44 differed significant from in plant height, number of leaves per plant, total biomass, harvest index and grain yield. FARO 44 differed significantly from NERICA 2 and FARO 15 at all the parameters under study. Water is very vital as far as rice production is concern should be applied at every stage of rice production. FARO 44 is recommended for the area for higher yield.
\end{abstract}

\section{Keywords}

Response; Rice Varieties; Water Stress; Sudan Savannah, Nigeria

\section{Introduction}

Rice (Oryza sativa L.) is the most important cereal crop in the world and it is the primary source of food and calories for about half of mankind [1]. More than $75 \%$ of the annual rice supply comes from 79 million hectares of irrigated paddy land. Irrigation is an important practice in agriculture, the competition for fresh water in the development of urbanization, industry, leisure, and agriculture causes the decline of fresh water for irrigation [2][4]. Water scarcity is a severe environmental limitation to plant productivity. Drought induced loss in crop yield may exceeds loses from all other causes, since both the severity and duration of the stress are critical [5].

According to [6] Stress has been define as "any environmental factor capable of inducing a potentially injurious strain in plants". Water is a major constituent of tissue, a reagent in chemical reaction, a solvent for and mode of translocation for metabolites and minerals within plant and is essential for cell enlargement through increasing

${ }^{*}$ Corresponding author. 
turgor pressure. With the occurrence of water deficits many of the physiological processes associated with growth are affected and under severe deficits, death of plants may result. The effect of water stress may vary with the variety, degree and duration of water stress and the growth stage of the rice crop. Water stress during vegetative stage reduces plant height, tiller number and leaf area. However, the effect during this stage varies with the severity of stress and age of the crop. Long duration varieties cause less yield damage than short duration varieties as long vegetative period could help the plant to recover when water stress is relieved. Leaf expansion during vegetative stage is very sensitive to water stress. Cell enlargement requires turgor to extend the cell wall and a gradient in water potential to bring water into the enlarging cell. Thus water stress decreases leaf area which reduces the intercepted solar radiation. Rice leaves in general have a very high transpiration rate thus under high radiation levels rice plant may suffer due to mid day wilting. Rice plant can transpire its potential rate even when soil moisture was around field capacity.

Water stress is one of the most limiting environmental factors to plant productivity world wide and can be caused by both soil and atmospheric water deficits. Water stress is one of the most limiting factors for plant survival since it regulates growth and development and limits plant productivity. The effect of water stress varies with variety, degree and duration of stress and the growth of the plant [7].

The effect of water stress on yield decrease of rice is very pronounced during certain period of growth, called the moisture sensitive periods. The most sensitive periods to water deficits are flowering and head development. In an experiment conducted in the Philippines [8]. It has been shown that moisture stress early in the growth of the rice reduced tillering, thereby reduced yield. When moisture stress was extended into reproductive phase, yield loss was significant. [9] examined the effect of varying soil water regime during different growth phaseson rice yield. They reported that the soil water stress applied any of the growth phases reduced rice grainyield, compared to the continuous flooding irrigation. The ripening phase appeared to be most sensitive to compared to the other phases. Soil water stress during the earlier growth phases (vegetative) appeared the production of effective tillers resulting in the reduction of grain yield, while stress during the later growth phases (reproductive) appeared to affect the reproductive physiology by interfering with pollination, fertilization and grain filling in the reduction of grain yield.

The objectives of this study are to examine the effects of water stress on growth and yield of three rice varieties in Sokoto.

\section{Materials and Method}

\subsection{Experiment Site}

Pot experiment was conducted during the 2013 dry season at the Botanical garden of the Department of Biological Science, Usmanu Danfordiyo University, Sokoto. Sokoto State is located between latitude $13^{\circ} 01^{\prime}$ North and longitude $05^{\circ} 15^{\prime}$ East of about $350 \mathrm{~m}$ above sea level.

The area has a long dry season that is characterized by cool dry air during harmattan from November to February and hot dry air during hot season from March to May. Relative humidity ranged from $26 \%$ - 39\% in the dry season. Minimum temperature ranged between $19^{\circ} \mathrm{C}$ and $29^{\circ} \mathrm{C}$ and maximum temperature ranged from 30 to $40^{\circ} \mathrm{C}$ and, wind speed ranged between 1.8 to $5 \mathrm{MS}^{-1}$ [(Sokoto Energy Research Center) (SERC, 2013)] (Appendix 1). Soil sample was collected from $0-20 \mathrm{~cm}$ soil depth and analyzed for physic-chemical characteristics. The soil of the experimental area is sandy, slightly acidic, low in organic carbon, total nitrogen, exchangeable cations and available phosphorous (Appendix 2).

Treatments consisted of factorial combination of water stress at three (3) critical growth stages (Tillering, Flowering and Grain filling) and unstress (control) and three varieties of rice (FARO 44, NERICA 2 and FARO 15), laid out in a Completely Randomized Design with three (3) Replications.

\subsection{Pot Preparation}

Pot was arranged according to the design layout Complete Randomized Design each pot containing $5.0 \mathrm{~kg}$ of the soil which was collected from the Fadama at Kwalkwalawa near the University. NPK 15:15:15 fertilizer was applied at the rate of $76 \mathrm{~kg} \mathrm{~N}, 30 \mathrm{~kg} P$ and $30 \mathrm{~kg} \mathrm{~K}$, the fertilizer was applied at basal and at 4 and 6 weeks after planting. Three varieties of rice were sown at the rate of $10 \mathrm{~g} /$ pot by broadcasting method; the seedlings were latter thinned to10 stands per pot. Weeding was done manually using hand at 2 - 3 and 5 - 6 weeks after planting. 
There was no record of pest and disease attack. Harvesting involves manual cutting and collection of matured rice panicles when the rice ripens in to a golden brown colour. Data was collected in respect of plant height, Number of leaves per plant, biomass, harvest index and grainyield. The data collected were subjected to the analysis of variance (ANOVA) and treatments were compared using Duncan's New Multiple Range Test (DNMRT).

\section{Results and Discussion}

\subsection{Plant Height}

The effect of water stress and variety on plant height is presented on Table $\mathbf{1}$. The result indicated that water stress had no significant $(P<0.05)$ effect on plant height at 3 Weeks After Planting (WAP). Water at tillering resulted to significant $(P<0.05)$ reduction in plant height at 6, 9, 12 and 15 WAP. Control (unstress) is statistically $(P<0.05)$ similar with water stress at flowering and grain filling. The reduction in plant height was as a result of water stress imposed at tillering stage. This is because imposing water stress resulted in law leaf water potentials and reductions in photosynthesis; photosynthetic activity declines because of decreased stomatal opening and the inhibition of chloroplast activity; this reduced the length of the internodes at jointing stage which follows tillering stage. At the time when water stress was imposed at flowering and grain filling, the jointing stage had taken place and plants have reached their maximum height, thus the effect of water stress was ineffective. [10] and [11] Found significant reductions in tillers and panicles numbers as well as plant height and grain yield when water stress was imposed at tillering stagewater stress resulted to decreased in plant height, number of tillers per plant, total biomass and grain yield [12]-[14].

The effect of variety showed that at 3 WAS varieties did not differ in plant height. But Faro 44 differed significantly with taller plants, while Wheata 4 and Nereca 2 did not differ significantly with shorter plants. The significant differences among genotypes for plant height indicate appreciable amount of variability among the genotypes. [15] subjected the varieties to moisture stress at different growth stages particularly during seeding stage. They identified some promising lines had tolerance to the water stress. [16] reported varietal differences among the cultivar for moisture stress.

Table 1. Effect of water stress and variety on plant height of rice at Sokoto.

\begin{tabular}{|c|c|c|c|c|c|}
\hline \multirow{2}{*}{$\begin{array}{c}\text { Treatments } \\
\text { Water Stress }\end{array}$} & \multicolumn{5}{|c|}{ Weeks after planting } \\
\hline & 3 & 6 & 9 & 12 & 15 \\
\hline Tillering & 17.13 & 29.43 & 46.79 & 60.39 & 60.41 \\
\hline Flowering & 17.06 & 33.11 & 51.63 & 68.16 & 68.46 \\
\hline Grainfilling & 17.56 & 3202 & 52.09 & 67.43 & 67.63 \\
\hline Control & 17.90 & 32.00 & 53.37 & 68.89 & 68.91 \\
\hline Significance & $*$ & $*$ & $*$ & $*$ & $*$ \\
\hline S.E \pm & 0.652 & 0.433 & 1.200 & 1.872 & 1.642 \\
\hline \multicolumn{6}{|l|}{ Variety } \\
\hline NERICA2 & 19.31 & $32.03^{b}$ & $51.39^{b}$ & $67.88^{\mathrm{b}}$ & $68.12^{\mathrm{b}}$ \\
\hline FARO44 & 20.68 & $35.56^{\mathrm{a}}$ & $55.76^{\mathrm{a}}$ & $74.12^{\mathrm{a}}$ & $74.36^{\mathrm{a}}$ \\
\hline FARO15 & 19.42 & $31.27^{\mathrm{b}}$ & $51.26^{\mathrm{b}}$ & $67.12^{\mathrm{b}}$ & $68.67^{\mathrm{b}}$ \\
\hline Significance & $*$ & $*$ & $*$ & $*$ & $*$ \\
\hline S.E \pm & 0.564 & 0.375 & 1.039 & 1.621 & 1.422 \\
\hline \multicolumn{6}{|l|}{ Interaction } \\
\hline WXV & NS & NS & NS & NS & NS \\
\hline
\end{tabular}

Within a treatment, mean in a column followed by the same letter(s) in superscript are not significantly different using LSD; NS = not significant, * = significant at $5 \%$. 


\subsection{Number of Tillers per Plant}

The effect of water stress and variety on number of tillers per plantis is presented in Table 2. Water stress at tillering resulted in significantly $(P<0.05)$ fewer number of tillers than water stress at flowering or grain filling and control (no stress) which were statistically at par with each other. The fewer tillers recorded at tillering could be as a result of water stress imposed at tillering because non-availability of water at tillering stage resultedin reduction in the amount of intercepted photosynthetically active radiation (PAR). Similarly, during tillering plant produces leaves and due to reduced growth as a result of water stress, the leaf initiation gets decreased and thus, tends to reduce tillering. [10] and [11] reported that significant reductions in tillers and panicles numbers as well as plant height and grain yield were found when water stress was imposed at tillering stage.

The effect of variety indicated that.FARO 44 differed significantly $(P<0.05)$ with higher number of tillers per plant, while FARO15 and NERICA 2 did not differ significantly with fewer number of tillers plant. The significant differences among genotypes for number of tillers indicate appreciable amount of variability among the genotypes. [15] identified promising lines tolerance to water stress. [16] reported varietal differences among the cultivar for moisture stress.

\subsection{Number of Leaves per Plant}

The effect of water stress and variety on number of leaves per plant is presented on Table 2. The result indicated that water stress had no significant effect on number of leaves per plant at 3 Weeks After Planting (WAP). Water at tillering resulted to significant $(P<0.05)$ reduction in number of leaves per plant at $6,9,12$ and 15 WAP. The reduction in plant height could be as a result of water stress imposed at tillering, which could result to decrease in photosynthesis and translocation of photosynthates. The decline in leaf number is due to death and abscission of leaves at faster rate as no new leaves were initiated during the reproductive stage. Significant reduction of number of leaves at tillering was as a result of water stress imposed at that stage, this was because law leaf water potential resulted in large reductions in photosynthesis, the reductions are caused both by decreases in the photosynthetic activity of a unit of leaf and in the production of new leaf surface.

Table 2. Growth and yield of three (3) rice varieties as influenced by water stress at Sokoto.

\begin{tabular}{|c|c|c|c|c|c|c|c|}
\hline Water stress & $\begin{array}{l}\text { Number of } \\
\text { tillers/plant }\end{array}$ & $\begin{array}{l}\text { Number of Leaves } \\
\text { per plant } 6 \text { WAP }\end{array}$ & $\begin{array}{l}\text { Number of Leaves } \\
\text { per plant } 9 \text { WAP }\end{array}$ & $\begin{array}{l}\text { Number of Leaves } \\
\text { per plant } 12 \text { WAP }\end{array}$ & Biomass & $\begin{array}{l}\text { Harvest } \\
\text { index }\end{array}$ & $\begin{array}{c}\text { Grain yield } \\
\text { t/ha }\end{array}$ \\
\hline Tillering & 5.19 & 12.44 & 19.33 & 19.89 & $4.66^{\mathrm{b}}$ & $23.84^{\mathrm{b}}$ & $1.111^{\mathrm{b}}$ \\
\hline Flowering & 9.29 & 15.89 & 22.67 & 23.11 & $5.68^{\mathrm{a}}$ & $15.65^{\mathrm{c}}$ & $0.889^{c}$ \\
\hline Grain filling & 9.33 & 15.00 & 22.56 & 23.44 & $5.59^{\mathrm{a}}$ & $15.65^{\mathrm{c}}$ & $0.889^{c}$ \\
\hline Control & 9.33 & 15.33 & 22.67 & 23.67 & $5.72^{\mathrm{a}}$ & $52.44^{\mathrm{a}}$ & $3.00^{\mathrm{a}}$ \\
\hline Significance & $*$ & $*$ & $*$ & * & $*$ & $*$ & $*$ \\
\hline $\mathrm{SE} \pm$ & 0.304 & 0.416 & 0.786 & 0.906 & 0.241 & 9.04 & 0.429 \\
\hline \multicolumn{8}{|l|}{ Variety } \\
\hline NERICA2 & $5.92^{\mathrm{b}}$ & $14.67^{\mathrm{b}}$ & $21.92^{\mathrm{b}}$ & $24.75^{\mathrm{b}}$ & $4.42^{\mathrm{b}}$ & $28.28^{\mathrm{b}}$ & $1.20^{\mathrm{b}}$ \\
\hline FARO44 & $8.25^{\mathrm{a}}$ & $16.50^{\mathrm{a}}$ & $24.33^{\mathrm{a}}$ & $26.75^{\mathrm{a}}$ & $5.69^{\mathrm{a}}$ & $57.11^{\mathrm{a}}$ & $3.25^{\mathrm{a}}$ \\
\hline FARO15 & $5.18^{\mathrm{b}}$ & $14.56^{\mathrm{b}}$ & $21.89^{b}$ & $24.83^{\mathrm{b}}$ & $4.69^{\mathrm{b}}$ & $26.65^{\mathrm{b}}$ & $1.25^{\mathrm{b}}$ \\
\hline Significance & $*$ & $*$ & $*$ & * & * & * & $*$ \\
\hline $\mathrm{SE} \pm$ & 0.964 & 0.360 & 0.680 & 0.640 & 0.340 & 2.830 & 0.371 \\
\hline Interaction WX V & NS & NS & NS & NS & NS & NS & NS \\
\hline
\end{tabular}

Within a treatment, mean in a column followed by the same letter(s) in superscript are not significantly different using LSD; NS = not significant, * = significant at $5 \%$. 
The effect of variety showed that FARO 44 differed significantly $(P<0.05)$ with higher number of leaves per plant, while FARO 15 and NERIC 2 did not differ significantly with fewer number of leaves per plant. The significant $(P<0.05)$ differences among genotypes for plant height indicate appreciable amount of variability among the genotypes. [16] reported varietal differences among the cultivar for moisture stress.

\subsection{Biomass}

The effect of water stress and variety on biomassis is presented on Table 2. Water stress at tillering resulted in lower biomass than water stress at flowering and grain filling or no stress control which were statistically similar. Lower biomass was from water stress at tillering. This could be as a result of water stress imposed at tillering which could result to decrease in photosynthesis, translocation rate and dry matter accumulation. Similarly tillers per unit area, plants height, number of leaves all these contributes to biomass and all these components were affected by water stress.

The effect of variety showed that FARO 44 differed significantly $(P<0.05)$ with higher biomass, while FARO 15 and NERECA 2 did not differ significantly with lower biomass. This could be as a result of taller plants and higher plants produced by FARO 44. The significant differences among genotypes for biomass indicate appreciable amount of variability among the genotypes. [16] reported varietal differences among the cultivar for moisture stress.

\subsection{Harvest Index}

The effect of water stress and variety on Harvest index (HI) of threerice varieties is presented on Table 2. Water stress at flowering and grain filling resulted in lower $\mathrm{HI}$ than water stress at tillering and no stress control which are statistically similar with higher HI. Decrease in HI could be largely due to water stress which resulted to decrease in translocation of assimilates to the grains, which lowered grain weight and increased the empty grains. High HI indicate the efficient translocation of assimilates towards sink. Lower HI values under water stress at flowering and grain filling stages indicate that it was more harmful in translocation of assimilates towards the grains. This is in accord with that of [17] who observed highest HI well irrigated genotypes compared to that of the genotypes which were grown under water stress condition the result indicated that water stress at flowering and grain filling resulted in lower $\mathrm{HI}$ than water stress at tillering and no stress control which are statistically similar with higher HI. Decrease in HI could be largely due to water stress which resulted to decrease in translocation of assimilates to the grains, which lowered grain weight and increased the empty grains. High HI indicate the efficient translocation of assimilates towards sink. Lower HI values under water stress at flowering and grain filling stages indicate that it was more harmful in translocation of assimilates towards the grains. This is in accord with that of [17] who observed highest HI well irrigated genotypes compared to that of the genotypes which were grown under water stress condition.

The effect of variety showed that Faro 44 differed significantly $(P<0.05)$ with higher harvest index, while FARO 15 and NERICA 2 did not differ significantly with lower harvest index. The significant differences among genotypes for harvest index indicate appreciable amount of variability among the genotypes. [16] reported varietal differences among the cultivar for moisture stress.

\subsection{Grain Yield}

The effect of water stress and variety on grain yield $\left(\mathrm{t} \cdot \mathrm{ha}^{-1}\right)$ of three rice varieties is presented on Table 2 . Water stress at flowering and grain filling resulted to significant $(P<0.05)$ reduction in grain yield. Yield reduction due to water stress could be as a result of reduction in photosynthesis and translocation. There was a linear relationship between available water and yield, where reduction in available water limits evapotranspiration and consequently reduced yield, as reported by several researchers [18]. [19] reported that drought stress at duration of filling grains period with acceleration in ripening time, casing to growth period duration and filling grains decreased.

The effect of variety on grain yield indicated that Faro 44 differed significantly $(P<0.05)$ with higher grain yield, while FARO15 and NERICA 2 did not differ significantly with lower grain yield. The significant differences among genotypes for plant height indicate appreciable amount of variability among the genotypes. [16] reported varietal differences among the cultivar for moisture stress. 


\section{Conclusion}

The water stress applied after tillering initiation stage is more effective on grain yield and the other characters. FARO 44 exhibited better water stress tolerance and this variety proved the promising cultivar under water stress conditions or water limiting area.

\section{References}

[1] Khush, G.S. (2005) What It Will Take to Feed 5.0 Billion Rice Consumers in 2030. Plant Molecular Biology, 59, 1-6. http://dx.doi.org/10.1007/s11103-005-2159-5

[2] Bergez, J.E. and Nolleau, S. (2003) Maize Grain Yield Variability between Irrigation Stands: A Theoretical Study. Agricultural Water Management, 60, 43-57. http://dx.doi.org/10.1016/S0378-3774(02)00152-X

[3] Qadir, M. and Oster, J.D. (2004) Crop and Irrigation Management Strategies for Salinesodic Soils and Waters Aimed at Environmentally Sustainable Agriculture. Science of the Total Environment, 323, 1-19. http://dx.doi.org/10.1016/j.scitotenv.2003.10.012

[4] Zwart, S.J. and Bastiaanssen, W.G.M. (2004) Review of Measured Crop Water Productivity Values for Irrigated Wheat, Rice, Cotton and Maize. Agricultural Water Management, 69, 115-133. http://dx.doi.org/10.1016/j.agwat.2004.04.007

[5] Farooq, M., Wahid, A., Kobayashi, N., Fujita, D. and Basra, S.M.A. (2008) Plant Drought Stress: Effects, Mechanisms and Management. Agronomy for k Mechanisms and Management. Agronomy for Sustainable Development, 1-28.

[6] Department of Agriculture (2006) Government of Sri Lanka (DOASL), All Rights Reserved-Developed in Association with ICTA.

[7] Adejare, F.B. and Unebesse, C.E. (2008) Water Stress Induces Cultivar Department Changes in Stomatal Complex, Yield and Osmotic Adjustments in Glyche Max L. International Journal of Agricultural Research, 3, 287-295. http://dx.doi.org/10.3923/ijar.2008.287.295

[8] IRRI (1973) Water Management in Philippines Irrigation Systems-Water Stress Effects in Flooded Tropical Rice. Los Baños, Philippines.

[9] Jana, R.K. and Ghildyal, B.P. (1971) Effect of Varying Soil Water Regimes during Different Growth Phases on the Yield of Rice under Different Atmospheric Evaporative Demands. Il Riso Anno, xx, 31-37.

[10] Bahattacharjee, D.P., Krishnayya, G.R. and Ghosh, A.K. (1973) Analyses of Yield Components Andproductive Efficiency of Rice Varieties under Soilmoisture Deficit. Indian Journal of Agronomy, 16, 314-343.

[11] De Datta, S.K., Abilay, W.P. and Kalwar (1973) Water Stress Effect on Flooded Tropical Rice. Water Management in Philippines Irrigation System Research and Operation, 16-36.

[12] Tantawi, B.A. and Ghanem, S.A. (2001) Water Use Efficiency in Rice Culture. Agricultural Research Center, Giza (Egypt). CIHM-Optin Mediterraneennes, 40, 39-45.

[13] Rahman, M.T., Islam, M.T. and Islam, M.O. (2002) Effect of Water Stress at Different Growth Stages on Yield and Yield Contributing Characters of Transplanted Aman Rice. Pakistan Journal of Biological Sciences, 5, 169-172. http://dx.doi.org/10.3923/pjbs.2002.169.172

[14] Tuong, T.P., Bouman, B.A.M. and Mortimer, M. (2005) More Rice, Less Water-Integrated Approaches for Increasing Water Productivity in Irrigated Rice-BasedSystems in Asia. Plant Production Science, 8, 229-239. http://dx.doi.org/10.1626/pps.8.231

[15] Pramanik, S. and Grupta, S. (1989) Screening Advanced Breeding Lines and Germplasme for Drought Resistance under Uplandconditions. International Rice Research Newsletter, 14, 20.

[16] Singh U.P. and Sing, K. (1980) IR5178-1-1-4 an Outstanding Drought Tolerant Line. International Rice Research Newsletter, 5, 9.

[17] Sharma, K.D., Pannu, R.K., Tyagi, P.K., Chaudhary, B.D. and Singh, D.P. (2003) Effect of Moisture Stress on Plant Water Relations and Yield of Different Wheat Genotypes. Indian Journal of Plant Physiology, 8, 99-102.

[18] Shani, U. and Dudley, L.M. (2001) Field Studies of Crop Response to Water and Salt Stress. Soil Science. Society of America Journal, 65, 1522-1528. http://dx.doi.org/10.2136/sssaj2001.6551522x

[19] Boonjung, H. and Fukai, S. (1996) Effects of Soil Water Deficit at Different Growth Stages on Rice Growth and Yield Under Upland Conditions. Field Crops Research, 48, 47-55. http://dx.doi.org/10.1016/0378-4290(96)00039-1 
Appendix 1. Soil Physico-Chemical Properties of the Experimental Site during the 2013 Dry Seasons

\begin{tabular}{cc}
\hline Physical properties & 2013 dry season \\
\hline Sand $\left(\mathrm{g} \cdot \mathrm{kg}^{-1}\right)$ & 701 \\
Silt $\left(\mathrm{g} \cdot \mathrm{kg}^{-1}\right)$ & 127 \\
Clay $\left(\mathrm{g} \cdot \mathrm{kg}^{-1}\right)$ & Sandy loam \\
Textural class & \\
Chemical Properties & 6.4 \\
pH in $\left(\mathrm{H}_{2} \mathrm{O}\right) 1: 1 \mathrm{ratio}$ & 0.046 \\
Total nitrogen $\mathrm{g} \cdot \mathrm{kg}^{-1}$ & 16.98 \\
Organic C $\left(\mathrm{g} \cdot \mathrm{kg}^{-1}\right)$ & 1.64 \\
Available P $\left(\mathrm{mg} \cdot \mathrm{kg}^{-1}\right)$ & \\
Exchangeable bases $\left(\mathrm{C} \mathrm{mol} \cdot \mathrm{kg}^{-1}\right)$ & 2.4 \\
$\mathrm{Ca}$ & 1.9 \\
$\mathrm{Mg}$ & 1.56 \\
$\mathrm{~K}$ & 0.95 \\
$\mathrm{Na}$ & 8.4 \\
\hline $\left.\mathrm{C} \mathrm{mol} \cdot \mathrm{kg}^{-1}\right)$ & \\
\hline
\end{tabular}

\section{Appendix 2. Meteorological Data during the 2013 Dry Seasons at Sokoto}

\begin{tabular}{ccccc}
\hline Months & Mean Max Temp $\left({ }^{\circ} \mathrm{C}\right)$ & Mean Min Temp $\left({ }^{\circ} \mathrm{C}\right)$ & Relative Humidity $(\%)$ & AVG. Wind Speed (m/s) \\
\hline March & 40.8 & 28.0 & 17.00 & 1.8 \\
April & 42.0 & 29.7 & 28.28 & 2.6 \\
May & 40.8 & 26.3 & 49.08 & 3.8 \\
June & 39.0 & 24.2 & 18.20 & 1.9 \\
\hline
\end{tabular}

Source: Sokoto Energy Research Center UDUS. 